and has its entire collection available on on a single CD-ROM disk.

Scholastech Inc., P.O. Box 1768, Cambridge, MA 02238. A clearinghouse for MS DOS (PC DOS) public-domain software; send for their catalog.
If your library is already connected to Compuserve or The Source, both have substantial collections of public-domain software that can be downloaded.

\title{
Bamberg to Brown: A library exchange
}

\author{
By Florence K. Doksansky \\ AUL for Public Services and Collection Development \\ Brown University
}

\section{The merits and drawbacks of an overseas exchange.}

$\mathbf{F}$ or many years Brown University and the Universität Bamberg, West Germany, have had an exchange involving faculty and students. This was fostered by two academic professors who knew each other and who had research interests in common. The professors were also very interested in supporting an exchange for university staff. Some difficulties were encountered concerning the exchange of teaching staff; consequently it was decided to offer the opportunity to the professional library staff.

In November 1983 Professor Klaus Peter Jochum of Bamberg wrote to Brown's university librarian to describe a projected exchange which the university librarian, Merrily Taylor, agreed to pursue. In September 1984 another letter from Bamberg described the progress made in making arrangements within the German bureaucracy:

"The President, the Chancellor and the Library Director of the University are in favor of the exchange, and what is more important, the Ministry of Cultural Affairs [for Bavaria] has agreed in principle. The librarian in question will be permitted to retain her salary while on official leave of absence of up to six months."

Professor Jochum went on to describe the individual, Regina Krepulat, and noted that it would be advantageous to have a Brown librarian go to
Bamberg in exchange. Many letters and arrangements were necessary before Regina actually came to Brown two years after the initial request. Regina herself was instrumental in obtaining a leave from the Bavarian government, and also in successfully applying for a Fulbright grant to support her travel expenses.

As it turned out, it was almost as difficult to make the necessary arrangements in the United States as it had been in Germany. It was established that the German librarian's salary would not be enough to keep her afloat in the United States without an adjustment. Thanks to the cooperation of two professors at Brown's Office of International Studies, a sum was found to supplement the German salary.

At approximately the same time that the above negotiations were taking place, the Brown University Library had put in place a new program for professional librarians. This program includes a two-track promotional system, which encourages professional activities above high quality job performance as a means to promotion beyond the career rank. Research leaves as a means to facilitate professional activity were now in place.

Librarians with the higher professional ranks are eligible to request research leaves. These leaves provide up to six months of time for concentrated 
research investigation of substantive professional topics. Librarians who wish to apply for a leave must have it approved through appropriate administrative channels, including approval from the university librarian and the provost, six months prior to the leave. At Brown a librarian is eligible for a leave every six years, and if a leave is taken the librarian is expected to return to full-time status at Brown for one year after the completion of the leave. The librarian is expected to present evidence of an attempt to find funding with the request for the leave. Usually the librarian is not replaced unless outside monies are available, since the librarian's salary and benefits are continued during the leave. When the leave is completed, a formal report or publication is required.

With this program in place, it was easier to find a Brown exchange partner to go to Bamberg. Following a brief description here of Regina Krepulat's exchange at Brown will be an article by Gretchen Yealy, serials cataloger at Brown, who spent three months in Bamberg in the spring of 1986.

Once everything, including living arrangements, was organized for Regina's visit, her exchange program was turned over to the library's Staff Development Committee. Fortunately, the committee included the collection development librarian for German literature, who had a master's degree in German from Brown, and a staff member from Special Collections whose husband is a professor in the German Department. These two staff members were assigned the task of designing a schedule for Regina, and also were asked to assist her whenever necessary. Regina arrived in September 1985 and left at the end of February 1986. As it turned out, it was important that staff at Brown were prepared to assist Regina on her arrival. There were problems with the initial housing arrangements, and one of the staff members kindly took Regina into her own home for a few days.

With the Staff Development Committee as hosts, the actual exchange ran very smoothly. Regina is a delightful person who has a very good command of English, and who gave an interesting international flavor to the staff during her visit. The program consisted of an orientation to every department in the Library, including Administration, Acquisitions, Cataloging, Government Documents, Interlibrary Loan, Circulation, Collection Development, Serials, and Special Collections. While in these departments she did various projects, and after her visit the department head was asked to make a report on Regina's assignment. This procedure encouraged those in charge to have her time organized, and this worked fairly well.

Regina spent almost every afternoon at the $\mathrm{Hu}$ manities/Social Sciences Reference Desk, where she got in-depth training in reference techniques. This part of the exchange was in response to her request for exposure to public services in American libraries. While Regina gained confidence with her transition to constant use of English, she was never totally comfortable at the reference desk, where language facility is essential. She had to depend on the staff to assist her with interpreting patron questions and formulating answers to them even towards the end of her visit. Considering that almost the entire collection of reference material was new to her, this should not have been unexpected. Fortunately most users and reference staff had a positive attitude toward the exchange so that it was not a major problem. However, it should be noted that this was a strain on the staff and certainly Regina's presence at the reference desk did not relieve any pressure felt at busy times. In retrospect, the amount of time she spent in reference was probably too great, and the amount of training she received too little for her to be effective. When involved in projects in other departments that did not require intense use of English, she was more productive and comfortable.

As facilitator and chair of the Staff Development Committee, I met with Regina regularly to answer questions that came up about the program and the workings to the Library. From an administrative point of view I would say that the exchange worked as a staff development program for Regina, and also for the Brown library staff. The latter gained experience from organizing her activities, and from training someone who had little familiarity with the attitudes, philosophy or resources of American libraries.

At the end of Regina's visit, she gave a presentation to the staff describing what she thought were the differences between her home library and Brown. It was clear from her talk that Regina had

\section{DIRECTORY OF SERVICES FOR REFUGEES AND IMMIGRANTS}

Comprehensive directory of nearly 900 ethnic, religious and community organizations and voluntary and governmental agencies providing direct social, economic, educational, cultural and legal services to refugees, immigrants and the undocumented in the US. Arranged by state. Fourteen indexes. 375 p. ISBN 0-938737-12-0. LCCN 87-70700. $\$ 27.95$

Coming this winter... Guide to Serial Publications of the Smithsonian Institution

The Denali Press

Post Office Box 021535 Juneau, Alaska $99802-1535$ (907) 586-6014 
had an extremely positive experience, that she had learned a great deal from these six months, and that she had enjoyed the atmosphere and style of the Brown University Library. Regina enjoyed working with Government Documents very much, and was amazed at the quantity and diversity of this material. Her introduction to computers was also of great interest to her. She had never had any "hands on" experience, and was pleased at the success she had with a brief word processing task. She was impressed with how work procedures change in a library that uses computers as extensively as Brown does. She was also surprised to see how much of Brown's copy cataloging is done by nonprofessionals, since this is considered one of the most important duties of the professional librarians in Germany. Her other revelation was the openness and participative style of the Brown library administration. She attended several senior staff meetings, and sat in on a variety of committees. In her own library neither visitors nor non-academic staff would ever be allowed to attend such meetings or participate in decision-making processes.

The exchange with Bamberg is Brown's first experience with this kind of staff development. Since last year, we have had three requests from libraries in other countries to visit us. While some will take place, others may not. Our experience with Regina Krepulat has shown us both positive and negative aspects of such a program. The time and patience involved in preparing for such a visit might be a de- terrent to some libraries, while the more demanding training time is another. While each department tried to use Regina's talents as best they could, it soon became obvious that some would benefit more from her visit than others. Although Regina had requested experience in public service areas, her time spent at the reference desk should have been brief. Projects could then have been assigned that would have been more productive for the Library, as well as satisfying for Regina.

I am still of the opinion that this was a valuable experiment, but I would not wish to handle an exchange of this length of time every year. Certainly a six-month exchange where the librarian spends most of the time learning about the library in a general way does not seem like the best use of anyone's time. I think the rest of the Brown staff and Regina would agree with this statement. The three-month period that the Brown staff member spent in Germany is a more appropriate length of time for this type of exchange. In fact, if Brown were to do this again, the overview of library activities would be very short, and a specific project would be assigned to the librarian for the duration of the exchange. If there was an exact job exchange, a longer period would be better since more productivity could be expected. It would seem essential to have some support mechanisms such as were available at Brown to enable a smoothly running exchange. While salary and housing problems may not occur on every exchange, there are bound to be some logistics

\section{United Kingdom Fulbright Award}

The United States-United Kingdom Educational Commission in London has announced the opening of the 1988-89 competition for the Fulbright professional librarian award to the United Kingdom. One award is available for an American librarian to pursue a work attachment at a university library, major research library, or national library in the United Kingdom. The purpose of the award is to promote the exchange of ideas between library staff in the U.S. and United Kingdom and to enable participants to acquire practical knowledge and experience of library work in a different cultural setting.

- Applicants must hold U.S. citizenship and a full-time library post as a librarian, library administrator, or archivist at a four-year college or university, or a major research library outside of higher education;

- A minimum of five years continuous professional experience is also required. A Master of $\mathrm{Li}$ brary Science degree is preferable, though extensive service may be substituted for the degree;

-Each applicant is responsible for arranging affiliation with one of the participating university libraries, research libraries, or national libraries in the United Kingdom;

- Affiliations are for the purpose of practical work experience-proposals of an academic or research-oriented nature are not appropriate for this professional award;

- The award is for a minimum period of three months. The grant period may begin any time after September 1, 1988, and may be of a duration of three to twelve months;

- Candidates are expected to be on approved leave of absence with full or partial compensation from their institution. Fulbright provides a modest fixed sum grant to cover travel and settling in expenses/incidentals.

For further information, application materials, and the list of eligible libraries in the United Kingdom, contact Steve Blodgett, Council for International Exchange of Scholars, Eleven Dupont Circle, N.W., Suite 300, Washington, DC 20036; (202) 939-5410.

All applications, including references and evidence of institutional affiliation in the United Kingdom, must be received by CIES before September 15, 1987 (NOTE: The deadline for 1988-89 has been changed). 
problems that someone will have to be responsible for solving. Programs that are established directly between libraries rather than between universities may have fewer complications. The Staff Development Committee is now writing guidelines for the library so that in the future an exchange might run more effectively.

There has to be some consideration on the part of the administration of what is gained in knowledge and experience in such a leave. There are some questions as to whether this is a true "research leave." It certainly was an activity which broadened the scope and breadth of knowledge for both of these professional librarians. Whether or not they will actually put to use skills or techniques learned during their visits is a moot question. In my opinion, it is significant that they both experienced a totally different environment from the one for which they had been trained. How many administrators have wished their staff had worked in more than one position in one location during their careers? Since they are both extremely intelligent young librarians, I hope that the exchanges will be one step in furthering their career development. Both have taken courageous steps into unknown environments, and have returned to their own home institutions revitalized and enthused over what they had learned. This alone may have been more than worth all the other costs.

\title{
Springtime in Germany
}

\author{
By Gretchen Yealy \\ Serials Cataloger \\ Brown University
}

\section{Another perspective-Brown goes to Bamberg.}

D uring the spring of 1986 I spent three months as an exchange librarian at the Universitätsbibliothek Bamberg in West Germany. I worked in each of the major library departments, with special emphasis on cataloging, my area of concentration at home at Brown University. While three months is hardly long enough to learn everything there is to know about a complex university library, I had a chance to observe routines both similar to and very different from those at home. In addition, I grappled with a number of cultural conflicts, both linguistic and professional in nature.

The Universität Bamberg is a relatively young German university. It was organized in the 1970s on the sites of earlier schools of pedagogy and theology in the northern Bavarian city of Bamberg. As is usual in Germany, there is no "campus." The uni- versity and its libraries are spread out among many old and new buildings in a lovely city of about 80,000 people. Bamberg escaped major damage during both world wars and attracts many tourists who crowd its picturesque market area and numerous churches. I wore out several pairs of shoes on the scenic cobblestone streets, and rejoiced with the tourists when the chilly, damp weather endemic to the area in early spring eventually gave way to the sunshine and warmth of May and June.

Dealing with a foreign language every day at work and on the streets was by far the most challenging aspect of the exchange for me. Regina Krepulat, my exchange partner, had spent six months at Brown during the fall of 1985 , and I had constantly been impressed by her skill and aplomb in speaking English. While my comprehension im- 